\title{
Economics of eradicating Foot-and-Mouth disease epidemics with alternative control strategies
}

\author{
Análisis económico de la erradicación de brotes de fiebre aftosa \\ usando estrategias alternativas de control \\ RHM Bergevoet ${ }^{\mathrm{a}^{*}}$, MAPM van Asseldonk \\ ${ }^{a}$ Agricultural Economics Research Institute, Wageningen University and Research, Wageningen, The Netherlands.
}

\begin{abstract}
RESUMEN
Este estudio presenta un análisis económico de las estrategias de control para la fiebre aftosa (FMD) en rebaños ganaderos. Estrategias de control de vacunación-para-vivir alternativas fueron comparadas a la estrategia que involucra el sacrificio de todos los animales susceptibles en una área de $1 \mathrm{~km}$ alrededor de los rebaños infectados, además de medidas estándares como el sacrificio de rebaños infectados, sacrificio preventivo de rebaños de contacto, establecimiento de control y zonas de vigilancia. Las estrategias de vacunación fueron distintas en relación con el radio de vacunación alrededor de los predios infectados ( $2 \mathrm{~km}$ versus $5 \mathrm{~km}$ ). Para ejemplificar las consecuencias económicas se usó el caso de Holanda. Estas estrategias fueron evaluadas para un área ganadera escasamente poblada (SPLA), con menos de 2 predios $/ \mathrm{km}^{2}$ y en un área ganadera densamente poblada (DPLA) con más de 4 predios $/ \mathrm{km}^{2}$. Los resultados para el modelo de presupuesto parcial FMD mostraron que para DPLA una estrategia de control que incluye un radio de vacunación de $2 \mathrm{~km}$ es económicamente más efectiva. Para SPLA, una estrategia de control que incluya un radio de sacrificio de $1 \mathrm{~km}$ alrededor de un predio infectado es económicamente más efectiva .
\end{abstract}

Palabras clave: fiebre aftosa, vacunación, modelo de simulación epidemiológica, economía de rebaños.

\section{SUMMARY}

The paper presents an economic analysis of Foot-and-Mouth Disease (FMD) control strategies for livestock herds. Alternative vaccination-to-live control strategies were compared to the strategy that involves culling of all susceptible animals in an area of $1 \mathrm{~km}$ around infected herds in addition to standard measures as culling of infected herds, pre-emptive slaughter of contact herds, establishment of control and surveillance zones. Vaccination strategies differed with respect to the radius of vaccination around infected farms $(2 \mathrm{~km}$ versus $5 \mathrm{~km})$. As an example to illustrate the economic consequences the Netherlands was used. These strategies were evaluated for a Sparsely Populated Livestock Areas (SPLA) with less than 2 farms $/ \mathrm{km}^{2}$ and a Densely Populated Livestock Areas (DPLA) with more than 4 farms $/ \mathrm{km}^{2}$. Results of the partial budgeting FMD model revealed that for DPLA a control strategy which includes a vaccination radius of $2 \mathrm{~km}$ is most cost effective. For SPLA a control strategy which includes a $1 \mathrm{~km}$ culling radius around an infected farm is most cost effective.

Key words: Foot-and-Mouth disease, vaccination, epidemiological simulation model, livestock economics.

\section{INTRODUCTION}

Around the world, many countries are officially free from Foot-and-Mouth Disease (FMD) without preventive vaccination. Other countries are free from FMD but apply preventive vaccination, and in some countries FMD is still endemic (Paton et al 2009). Routine, preventive vaccination is banned under EU law, allowing the EU to maintain the highest FMD status under international trade rules of "countries free from foot-and-mouth disease without vaccination". An outbreak of FMD in a country that was until then free is confronted with severe adverse impacts on its livestock sector such as export blocks of susceptible

\footnotetext{
Accepted: 27.02.2014

\# Funded by the Dutch Ministry of Economic Affairs.

* ron.bergevoet@wur.nl
}

animals and their products to other countries. Therefore it is of utmost importance for a country to eliminate such an infection as rapidly as possible.

Large scale preventive culling was the control strategy used in a number of countries, free from foot-and-mouth disease without vaccination, when confronted with a new outbreak (Huirne et al 2002, Haydon et al 2004). Still most contingency plans foresee culling as the main component to control an outbreak. Yet large scale culling is believed to have had a devastating impact on society, animal welfare and environment and it is associated with high economic losses. Previous mass culling during epidemics caused societal outcry and disturbance (Cohen et al 2007).

In a number of countries adopting alternative strategies for control of future epidemics was imperative. This led to an increasing demand to reconsider the non-vaccination policy, and to discuss alternative future strategies that would be acceptable to, and supported by society at large and minimize 
financial and/or environmental impact ${ }^{1,2}$ (Parent et al 2011, Bergevoet et al 2011, Boklund et al 2013). In this paper we will explore the potential impact of alternative strategies to control an outbreak of FMD. It will give insight into potential costs and benefits of different control strategies that include a vaccination-to-live strategy. The Netherlands will be the country used for this illustration. Special emphasis will be given to economic differences among alternatives focussed on the impact of farm density, total costs, specific losses stemming from vaccinated animals, and distribution of costs between stakeholders and livestock sectors.

The introduction of the FMD virus in the Netherlands represents a major risk to the Dutch livestock industry, as around 17 million cattle, pigs and sheep are susceptible. FMD outbreaks in the past have shown that substantial parts of the livestock sector are confronted with large economic losses. As shown by the FMD epidemic in 2001-2002 in the Netherlands, not only the livestock sector was confronted with serious financial consequences and restrictions but the epidemic also had a large impact on society as a whole. This event did cost the Dutch society an amount of $€ 900$ Million or $0.2 \%$ of its annual Gross Domestic Product. These cost can be divided into different costs components, namely direct costs (enforcement costs, compensation of culled animals, screening etc.) amounting to $€ 90$ million, indirect and export market losses were $€ 320$ million, other parts of the livestock chain incurred a loss of $€ 215$ million, and the tourism and recreation sector $€ 275$ million (CPB 2001 cited by Huirne et al 2002).

The EU describes a number of requirements to contain an outbreak of FMD. This EU minimum strategy consists of culling of infected farms, tracking and tracing of risky contacts and establishment of inspection zones $(3 \mathrm{~km})$ and surveillance zones $(10 \mathrm{~km})^{3}$. Additional measures have to be taken to contain an outbreak in high animal density areas. This can be pre-emptive culling of farms in the neighbourhood of infected farms or emergency vaccination. After the last outbreak of FMD in the Netherlands emergency vaccination is preferred to pre-emptive culling. The term 'emergency vaccination' can have different connotations, but is usually applied to differentiate between routine,

1 DEFRA. 2011. Foot and Mouth Disease Control Strategy for Great Britain, November 2011, www.gov.uk/government/uploads/system/ uploads/attachment_data/file/69456/fmd-control-strategy111128.pdf

2 Bergevoet RHM, MAPM Van Asseldonk, M Bokma-Bakker, N Denormandie, A De Koeijer, P Marchot, HW Saatkamp, N Santini, E Wilkens. 2011. Feasibility study on the revision of Council Decision 2009/470/EC (ex 90/424/EEC) on expenditure in the veterinary field with a view to develop a harmonized EU framework for cost and responsibility sharing schemes for animal diseases. EU DG Sanco.http://ec.europa.eu/food/animal/diseases/strategy/pillars/ docs/653006_final_report_08062011.pdf

3 Council Directive 2003/85/EC of 29 September 2003 on Community measures for the control of foot-and-mouth disease repealing Directive 85/511/EEC and Decisions 89/531/EEC and 91/665/EEC and amending Directive 92/46/EEC (1) http://eur-lex.europa.eu/ LexUriServ/LexUriServ.do?uri=OJ:L:2003:306:0001:0087:EN:PDF prophylactic (preventive) vaccination and emergency vaccination, the latter being applied as an immediate response to an outbreak of disease. In the Dutch contingency plans vaccinated animals are not instantly slaughtered at the end of the outbreak but are kept for their normal productive lives (i.e., vaccination-to-live strategy). However, several concerns related to applying emergency vaccination exist. For instance, there is the question whether vaccination is as effective in controlling the epidemic as pre-emptive ring culling, because vaccinated animals are not instantaneously protected against infection. Another concern focuses on the cost-effectiveness of vaccination strategies. Since applying a vaccination-to-live strategy is relatively new in the EU, market acceptance of products originating from FMD vaccinated animals by retail and trade partners, might be an issue as well.

The objective of the study is to investigate the effectiveness and economic impact of alternative vaccination-to-live strategies for FMD epidemics. To evaluate the effectiveness, vaccination-to-live strategies within a $2 \mathrm{~km}$ or $5 \mathrm{~km}$ radius were compared with the EU minimum strategy and a strategy that required culling within a $1-\mathrm{km}$ radius around infected farms.

\section{MATERIAL AND METHODS}

\section{CONTROL STRATEGY AND FARM DENSITY}

The epidemic and economic outcomes of an FMD outbreak depends on the control strategy chosen and on the farm density in the area in which an outbreak occurs. Four alternative control strategies were evaluated: 1) the EU minimum strategy (EU-min), 2) a culling strategy (Cul1) which foresees culling of all FMD susceptible infected animals in a radius of $1 \mathrm{~km}$ around infected farms on top of the EU-min strategy; two preventive vaccination strategies were included which differed with respect to the vaccination radius, namely 3) $2 \mathrm{~km}$ (Vac2) and 4) $5 \mathrm{~km}$ (Vac5) around infected farms. Both vaccination strategies were in addition to the EU-min strategy, while during the first week of the outbreak the Cul1 strategy would be implemented (a maximum delay for the start of vaccination of one week was anticipated for preparation and EU approval of the vaccination strategy).

The effect of the identified strategies in two classes of farm density are distinguished, namely a Sparsely Populated Livestock Areas (SPLA) and a Densely Populated Livestock Areas (DPLA). A SPLA is defined as an area in which the farm density is less than 2 farms per $\mathrm{km}^{2}$. A DPLA is defined as an area in which the farm density is larger than 2 farms per $\mathrm{km}^{2}$. As a typical Dutch example, a region with more than 4 farms per $\mathrm{km}^{2}$ was analysed.

\section{EPIDEMIOLOGICAL SIMULATION MODEL}

The current analysis is based on a FMD transmission model which consists of a stochastic epidemiological 
simulation model. It was developed to investigate the consequences of the aforementioned alternative control strategies, and is described in detail by Backer et al (2012a, $2012^{\mathrm{b}}$ ). The model consists of two modules that describe the within-herd and between-herd transmission dynamics. For the within-herd module, that is formulated in terms of individual animals, parameters are estimated for cattle, sheep and pigs from literature on transmission and vaccination experiments (see Backer et al 2012 ${ }^{\mathrm{b}}$ for the model parameters for the within herd module). The within-herd module simulates a farm outbreak. The infection pressure (i.e. number of infectious animals as a function of time) of the herd is then used in the between-herd module. The transmission at this level is modelled by distance-dependent probabilities, estimated from the outbreak data of 2001 in the Netherlands, and by taking species-dependent transmission into account. To apply the model to the current situation, it needs the locations and type of all farms in the Netherlands, which are available for 2006 from databases. The between-herd module determines which herds are infected at what time by the source herd and which herds need to be culled or vaccinated, depending on the control strategy (see Backer et al 2012 ${ }^{\mathrm{b}}$ for the transmission matrix resulting from the relative herd susceptibility and the relative herd infectivity). This information on infection, vaccination and culling times is then used in the within-herd module to simulate the outbreak in the next infected farm. The result - after the last farm has been vaccinated or culled - is the total course of the hypothetical epidemic. This model structure allows for the extrapolation of the effects of vaccinating individual animals to the level of an area with many farms (Backer et al 2012a , Backer et al $2012^{\mathrm{b}}$ ). Given the stochastic nature of the model, the model was run one thousand times per investigated strategy to get insight into the distribution of possible outcomes.

The simulated epidemiological outcomes were used as input for the economic evaluation of the different control strategies. To calculate the economic effects the following epidemiological characteristics were subsequently used: the duration of the epidemic, the number of farms that were infected, culled, and/or vaccinated, located in a transport prohibition area, and the farm type (cattle, pig, sheep, hobby).

\section{ECONOMIC MODEL}

To evaluate the economic consequences of the different control strategies a partial budget model was developed (Dijkhuizen and Morris 1997). Costing components accounted for are summarised in table 1. Economic parameters were estimated from previous outbreaks and discounted to reflect current prices. Cost parameters are based on among others Meuwissen et al (1999), Mangen et al (2002), Huirne et al (2002) and Meuwissen et al (2003).

In contrary to other costing components the value loss of products of vaccinated animals cannot be ascertained from previous outbreaks.
After an end-screening to prove that the Netherlands is free of FMD the EU can allow export of products to other Member States in the EU (approximately 30 days after last detection). Export of non-vaccinated animals and products originating from these animals within the EU is allowed. Vaccinated animals are confined to the vaccination area for the rest of their lives.

Products of vaccinated animals have to be processed separately (logistic slaughtering or processing) from the products of non-vaccinated animals, resulting in a reduced market access (especially for countries outside the EU) ${ }^{4}$. Logistic slaughtering and reduced market access of products of vaccinated animals confronts the industry with substantial costs (Meuwissen et al 2009). Due to volume and reduced market access there will be value loss of products stemming from vaccinated animals.

For dairy, the milk from vaccinated animals has to be logistically processed for a period of 150 days after the outbreak and corresponding costs were accounted for. It was assumed the milk was used for cheese production. There is value loss because the side products of cheese production as whey, butter and buttermilk powder cannot be processed in the normal production routine. Due to the increase in scale of the dairy processing industry, it is not possible to separate and process these products to create normal added value with vaccination as a control strategy.

Revenue losses of vaccinated veal calves are substantial (Backer et al 2012 ${ }^{\mathrm{b}}$ ). This is due to the fact that the veal calf sector expects that the meat of vaccinated calves has to be sold as low value mincemeat to third countries without a FMD-free status.

Being a seasonal breeder the losses due to reduced revenues for sheep depend to a large extent on the moment of the outbreak and vaccination. The impact on the losses of an outbreak in spring will be different from the impact in autumn when all slaughter lambs are almost ready for market.

Not only meat from vaccinated pigs pose a loss (Hoste and Bergevoet 2007); also vaccinated piglets and piglets born from vaccinated sows present an additional challenge for the pig industry ${ }^{5}$. The Netherlands exports large numbers of live piglets to neighbouring member states.

4 During an on-going epidemic there is no difference between the possible destinations of vaccinated and non-vaccinated animals and their products in movement restriction zones. It is not possible to transport animals from farms. In case of a prolonged duration of the outbreak exemptions might be made for movement of animals from farms during the outbreak phase. Only farms with severe welfare problems will be able to move animals under very strict conditions. Products of these animals are under present agreement between government and livestock sector can only be sold to domestic markets.

5 Bergevoet RHM, SMA Kroon, WHM Baltussen, R Hoste, GBC Backus, JA Backer, TJ Hagenaars, B Engel, MD Jong, HJW Roermund. 2007. Vaccinatie bij varkenspest: epidemiologische en sociaaleconomische effecten. (Vaccination against Classical swine fever: epidemiological and economic effects) LEI, Den Haag, Netherlands. http://edepot.wur.nl/20604 
Table 1. Input parameters used for the economic evaluation.

Parámetros de entrada usados para la evaluación económica.

\begin{tabular}{|c|c|c|}
\hline Costing component & Value & Unit \\
\hline \multicolumn{3}{|l|}{ Value culled animals } \\
\hline Dairy cows & 759 & $€ /$ animal \\
\hline Young stock & 577 & $€ /$ animal \\
\hline Veal calves & 411 & $€ /$ animal \\
\hline Other cattle & 759 & $€ /$ animal \\
\hline Ewe (including lambs) & 73 & $€ /$ animal \\
\hline Sows (including piglets) & 522 & $€ /$ animal \\
\hline Fattening pigs & 77 & $€ /$ animal \\
\hline \multicolumn{3}{|l|}{ Destruction feed and milk } \\
\hline Dairy cows (including young stock) & 44.00 & $€ /$ animal \\
\hline Veal calves & 26.00 & $€ /$ animal \\
\hline Other cattle & 33.30 & $€ /$ animal \\
\hline Ewe (including lambs) & 1.60 & $€ /$ animal \\
\hline Sows (including piglets) & 33.00 & $€ /$ animal \\
\hline Fattening pigs & 3.70 & $€ /$ animal \\
\hline \multicolumn{3}{|l|}{ Clearing and disinfection } \\
\hline Dairy cows (including young stock) & 1000 & $€ /$ animal \\
\hline Veal calves & 150 & $€ /$ animal \\
\hline Other cattle & 1000 & $€ /$ animal \\
\hline Ewe (including lambs) & 100 & $€ /$ animal \\
\hline Sows (including piglets) & 400 & $€ /$ animal \\
\hline Fattening pigs & 150 & $€ /$ animal \\
\hline \multicolumn{3}{|l|}{ Empty farm buildings during outbreak } \\
\hline Dairy cows (including young stock) & 5.27 & $€ /$ day \\
\hline Veal calves & 0.13 & $€ /$ day \\
\hline Other cattle & 0.07 & $€ /$ day \\
\hline Ewe (including lambs) & 0.26 & $€ /$ day \\
\hline Sows (including piglets) & 0.96 & $€ /$ day \\
\hline Fattening pigs & 0.18 & $€ /$ day \\
\hline \multicolumn{3}{|l|}{ Costs of vaccinating } \\
\hline Dairy cows (including young stock and other cattle) & 8.80 & $€ /$ animal \\
\hline Veal calves & 2.60 & $€ /$ animal \\
\hline Ewe (including lambs) & 2.60 & $€ /$ animal \\
\hline Sows (including piglets) & 7.20 & $€ /$ animal \\
\hline Fattening pigs & 1.80 & $€ /$ animal \\
\hline \multicolumn{3}{|l|}{ Costs of transportation prohibition } \\
\hline Dairy cows (including young stock and other cattle) & 5.46 & $€ /$ animal \\
\hline Veal calves & 10.08 & $€ /$ animal \\
\hline Ewe (including lambs) & 1.68 & $€ /$ animal \\
\hline Sows (including piglets) & 17.64 & $€ /$ animal \\
\hline Fattening pigs & 2.10 & $€ /$ animal \\
\hline \multicolumn{3}{|l|}{ Value loss of vaccinated animals } \\
\hline Dairy cows & 450 & $€ /$ animal \\
\hline Young stock & 5 & $€ /$ animal \\
\hline Veal calves & 550 & $€ /$ animal \\
\hline Other cattle & 26 & $€ /$ animal \\
\hline Sows & 260 & $€ /$ animal \\
\hline Fattening pigs & 50 & $€ /$ animal \\
\hline Sheep & 34 & $€ /$ animal \\
\hline
\end{tabular}


The acceptance of vaccinated piglets, both domestically as well as on the export market, is expected to be limited. Therefore it is expected that vaccinated piglets may need to be slaughtered logistically and the revenues of the products of these animals will be lower. This can result in serious economic consequences for vaccinated sow farms.

\section{RESULTS}

Since the epidemiological consequences of the different control strategies are comprehensively described in Backer et al $\left(2012^{\mathrm{a}}\right.$ and $\left.2012^{\mathrm{b}}\right)$ in terms of probability distributions only the descriptive statistics are presented as the mean value and the 5\% percentile and the $95 \%$ percentile. Duration of an outbreak, the number of farms infected, culled and vaccinated differ substantially between region and control strategy (table 2).

The epidemiological simulation outcomes predict that in a DPLA the EU-min strategy will too often result in a lengthy outbreak, and therefore is not likely to be a preferred option for stakeholders involved. In a DPLA the $2 \mathrm{~km}$ vaccination strategy is less effective than $1 \mathrm{~km}$ culling in terms of both outbreak size and duration. Yet the number of preemptively culled farms using the culling strategy is large compared to the outbreak size (approximately a factor 20 in DPLA's), due to the high farm densities.
Interestingly, the number of preemptively culled farms is comparable to the number of detected and culled farms in the minimal strategy, meaning that either strategy will lead to large numbers of culled farms. The outbreak duration is shorter for a $5 \mathrm{~km}$ vaccination strategy compared to the $1 \mathrm{~km}$ culling and $2 \mathrm{~km}$ vaccination strategy. Given both vaccination strategies the number of culled farms is much smaller, even though large numbers of farms are affected by the control measures (ratio of vaccinated farms and outbreak size is 30 for $2 \mathrm{~km}$ vaccination and 100 for $5 \mathrm{~km}$ vaccination).

Epidemics are much smaller in SPLA's in terms of both outbreak duration and size. Due to the smaller epidemics, the absolute differences between the control strategies are marginalised. As long as the epidemic is confined in a SPLA, the minimal strategy is sufficient to control the epidemic and additional control measures do not provide much added value. However, the mean value ( 28 detected farms) exceeds the 95 percentile value ( 27 detected farms) indicating that incidentally an epidemic runs out of hand and very large numbers of farms need to be culled (mainly due to the spread of the infection to DPLA areas).

Effective control strategies from an epidemiological point of view do not necessarily imply efficient strategies from an economic point of view (table 3 ). Note that the EU-min strategy for the DPLA and DPLA is omitted

Table 2. Descriptive statistics of simulated epidemiological outcomes for different control strategies of epidemics that started in a SPLA and a DPLA region (hobby farms excluded).

Estadística descriptiva de los resultados epidemiológicos simulados para diferentes estrategias de control de epidemias que se iniciaron en una SPLA y en una región DPLA (parcelas excluidas).

\begin{tabular}{|c|c|c|c|c|c|c|}
\hline \multirow{2}{*}{ Area Strategy } & \multicolumn{3}{|c|}{ Duration in days } & \multicolumn{3}{|c|}{ Number of detected farms } \\
\hline & Mean & $5 \%$ & $95 \%$ & Mean & $5 \%$ & $95 \%$ \\
\hline DPLA EU-min & 254 & 166 & 375 & 1578 & 1099 & 2091 \\
\hline DPLA Cul1 & 61 & 25 & 111 & 48 & 17 & 94 \\
\hline DLPA Vac2 & 70 & 33 & 118 & 78 & 22 & 158 \\
\hline DPLA Vac5 & 47 & 25 & 78 & 46 & 19 & 88 \\
\hline SPLA EU-min & 36 & 7 & 90 & 28 & 4 & 27 \\
\hline SPLA Cul1 & 23 & 6 & 56 & 8 & 3 & 16 \\
\hline SPLA Vac2 & 24 & 6 & 57 & 9 & 3 & 19 \\
\hline \multirow[t]{3}{*}{ SPLA Vac5 } & 22 & 6 & 49 & 8 & 3 & 16 \\
\hline & \multicolumn{3}{|c|}{ Number of pre-emptively culled farms } & \multicolumn{3}{|c|}{ Number of vaccinated farms } \\
\hline & Mean & $5 \%$ & $95 \%$ & Mean & $5 \%$ & $95 \%$ \\
\hline DPLA EU-min & 463 & 355 & 572 & 0 & 0 & 0 \\
\hline DPLA Cul1 & 1015 & 336 & 1814 & 0 & 0 & 0 \\
\hline DLPA Vac2 & 199 & 92 & 333 & 2340 & 676 & 4075 \\
\hline DPLA Vac5 & 188 & 84 & 321 & 3963 & 1831 & 6629 \\
\hline SPLA EU-min & 8 & 0 & 8 & 0 & 0 & 0 \\
\hline SPLA Cul1 & 66 & 16 & 161 & 0 & 0 & 0 \\
\hline SPLA Vac2 & 25 & 5 & 53 & 142 & 0 & 428 \\
\hline SPLA Vac5 & 25 & 5 & 53 & 564 & 0 & 1380 \\
\hline
\end{tabular}


Table 3. Descriptive statistics of simulated economic outcomes for different control strategies of epidemics that started in a SPLA and a DPLA region.

Estadística descriptiva de los resultados económicos simulados para diferentes estrategias de control de las epidemias que se iniciaron en una región SPLA y en una DPLA.

\begin{tabular}{lccc}
\hline \multirow{2}{*}{ Area Strategy } & \multicolumn{3}{c}{ Total losses (in Million €.) } \\
\cline { 2 - 4 } & Mean & 5\% percentile & $95 \%$ percentile \\
\hline DPLA cul1 & 193 & 64 & 349 \\
DPLA vac 2 & 163 & 61 & 284 \\
DPLA vac 5 & 170 & 77 & 286 \\
SPLA EU-min & 68 & 18 & 107 \\
SPLA cul1 & 61 & 24 & 105 \\
SPLA vac 2 & 60 & 21 & 105 \\
SPLA vac 5 & 66 & 23 & 121 \\
\hline
\end{tabular}

Table 4. Loss of different sectors due to logistic processing and value loss given a vaccination strategy (in million $€$ ).

Pérdidas de los diferentes sectores debido al procesamiento logístico y pérdida de valor por estrategia de vacunación (millones de €).

\begin{tabular}{|c|c|c|c|c|c|c|c|c|c|}
\hline \multirow{2}{*}{$\begin{array}{c}\text { Area } \\
\text { Strategy }\end{array}$} & \multicolumn{3}{|c|}{ Cattle } & \multicolumn{3}{|c|}{ Sheep } & \multicolumn{3}{|c|}{ Pigs } \\
\hline & Mean & $5 \%$ & $95 \%$ & Mean & $5 \%$ & $95 \%$ & Mean & $5 \%$ & $95 \%$ \\
\hline DLPA Vac2 & 40.64 & 12.09 & 71.26 & 1.07 & 0.29 & 2.02 & 32.26 & 9.60 & 53.58 \\
\hline DPLA Vac5 & 68.70 & 31.99 & 31.99 & 2.11 & 0.81 & 3.93 & 48.51 & 24.25 & 77.33 \\
\hline SPLA Vac2 & 2.44 & 0.00 & 7.55 & 0.14 & 0.00 & 0.38 & 0.47 & 0.00 & 1.64 \\
\hline SPLA Vac5 & 9.59 & 0.00 & 24.02 & 1.45 & 0.00 & 1.45 & 1.30 & 0.00 & 5.66 \\
\hline
\end{tabular}

because it is a too risky strategy. In DPLA's the Vac2 strategy entails the lowest average loss. However, under favorable circumstances with limited spread the preferred strategy is Cul1 (see $5 \%$ percentile), while under adverse circumstances the Vac5 strategy is preferred (see 95\% percentile). Differences between the strategies in SPLA's are relative minor.

Shifts in costing components have implications for stakeholders involved (figure 1). EU community measures related to outbreaks of epidemic livestock diseases include co-financing of veterinary emergency measures. Council Decision 90/424/EEC allows for co-financing 60\% for FMD of the costs of compulsory and pre-emptive slaughter and of related operational expenditure (Bergevoet et al 2011). In addition, the remaining costs for these specific components are shared between the Dutch government and the livestock farmers by means of a compulsory public statutory compensation scheme (Van Asseldonk et al 2006). Indirect losses like value loss of vaccinated animals and its products are not eligible for compensation. As a consequence a larger amount of the losses are borne by farmers given a vaccination strategy (figure 1). For an outbreak in a DPLA in case of a Cul1 strategy the fraction of costs non-eligible is $13 \%$ and this fraction increases to $46 \%$ in case of a Vac5 strategy.

The incurred costs of logistic processing and value losses of vaccinated animals and its products differ between the livestock sectors (table 4). Of the total costs for the cattle sector $59 \%$ of the costs are related to the dairy sector and $40 \%$ related to the veal calf sector, costs related to young stock and other cattle are only $1 \%$ of the total costs. In the pig sector $53 \%$ are related to sow breeding farms and $47 \%$ to the fattening farms. Additional losses in the hobby sector are practically non-existing as a result of implementing a vaccination strategy.

\section{DISCUSSION}

By means of a stochastic modelling approach alternative vaccination-to-live control strategies were compared to the strategy that involves culling of all susceptible animals in an area of $1 \mathrm{~km}$ around infected herds in addition to standard measures as culling of infected herds, pre-emptive slaughter of contact herds, establishment of control and surveillance zones. The Netherlands has only suffered from FMD epidemics incidentally. Therefore the historic input data were complemented with reasoned assumptions. Furthermore, some input data (like the between-herd transmission) were only available for virus strain O/NET/2001. Although simulation estimates are less accurate with respect to the absolute estimated levels, they do proved a solid basis to estimate the relative differences between the vaccination-to-live control strategies and non-vaccination control strategies. Sensitivity analysis of the most important input pareameters based on expert opinion or based on historical data showed that the ranking order 

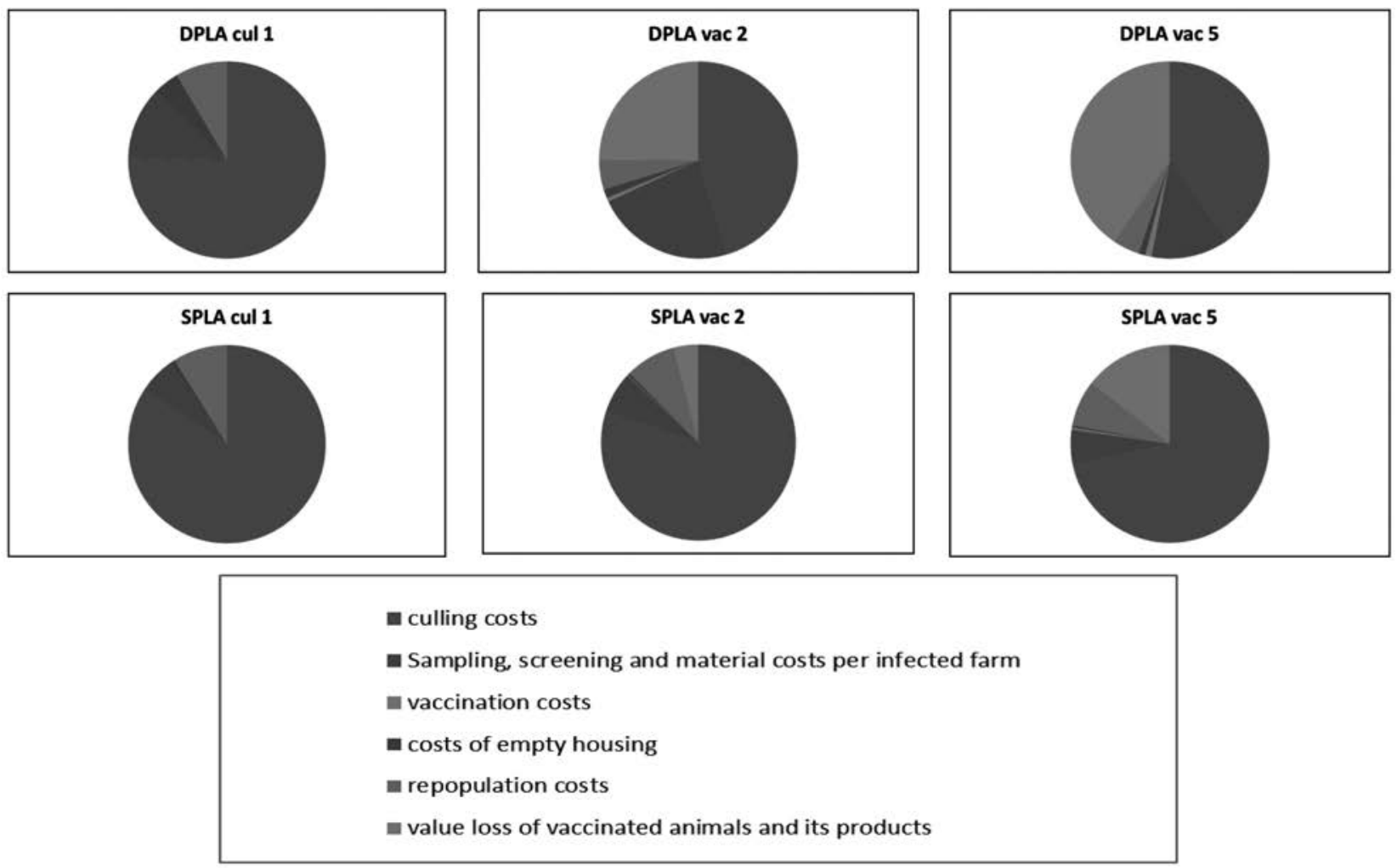

Figure 1. Distribution of the different costs that occur during an outbreak.

Distribución de los diferentes costos durante un brote de enfermedad.

was robust. Model outcomes predict that for the Dutch situation a culling strategy is the economically preferred strategy in SPLA, while a vaccination-to-live strategy is the economically preferred strategy in DPLA.

In the partial budget model only those costing components that differ between the evaluated alternatives are included. Therefore, the types of costs that do not or only differ marginally between strategies, and thus do not alter the ranking of the strategies, were excluded from the calculations. Excluded costs were for example domestic price effects due to export restrictions within the EU and to third countries, and the effect of the outbreak on prices in infected regions versus non-infected regions. Also the impacts on other businesses in the livestock value chain, non-FMD sensitive livestock branches and non-agricultural industries as tourism were not considered because losses are incurred mainly due to the fact of an occurring outbreak and to a lesser extend to the applied control strategy.

Although vaccination can limit the costs of an epidemic it also introduces the potential problem of reduced market access for products of vaccinated animals. Irrespective of a vaccination strategy or non-vaccination strategy export is prohibited to EU and third countries markets for live animals, meat and meat products from all regions in the Netherlands and for milk and milk products from infected compartments during the outbreak and the 30 day period after last detection. After this period, export is prohibited to only third countries of live animals, meat, meat products, milk and milk products from infected compartments for another 60 days if a non-vaccination strategy is applied. Given a vaccination-to-live control strategy this period is 150 days (according to OIE standards). It is assumed that export volumes recover after this period to the prior levels, independent of chosen strategy. The total effects of the export losses are determined by size and duration of the outbreak, control strategy applied and especially the country/area affected. Therefore they vary substantially and can only be determined after the outbreak.

An epidemic of FMD will result in trade restrictions that are to a large extent related to the epidemic per se and do not depend on the specific characteristics of the control strategy chosen.

It can be concluded that decision making in controlling contagious animal diseases is a complex process, characterized by a mixture of epidemiological, economic and social ethical value judgements. Different stakeholders will have different ideas about which strategy prevails. Their views may, for instance, represent the interests of the farming community, the processing industry, the animals, the consumer or the general citizen. This may create a situation of conflicting interests, as economic motives may prevail in the views of some, while animal or human welfare motives may be prominent in the view of others (Mourits et al 2010). Simulation outcomes reveal 
that vaccination for the Netherlands in a radius of $2 \mathrm{~km}$ in case of an outbreak of FMD in a DPLA is as effective as culling in a $1 \mathrm{~km}$ radius, whereas the economic and social effects are substantially smaller. For SPLA's absolute differences between the analysed control strategies in terms of epidemiological, economic and social ethical issues are of less concern. Although Boklund et al (2013) showed a similar ranking of strategies based on epidemiological simulation their overall economic evaluation showed higher economic losses in case a vaccination to live strategy was applied. The reason for this is the high dependency of the Danish pig on export to third countries.

Generalizing the findings of the results presented in this research to other countries should be done with great care although the presented approach can be used by other countries to get insight into the ranking of optional control strategies.

\section{REFERENCES}

Backer JA, B Engel, A Dekker, HJW van Roermund. 2012a. Vaccination against foot-and-mouth disease II: Regaining FMD-free status. Prev Vet Med 107, 41-50.

Backer JA, TJ Hagenaars, G Nodelijk, HJW van Roermund. 2012 . Vaccination against foot-and-mouth disease I: Epidemiological consequences. Prev Vet Med 107, 27-40.

Berentsen PBM, AA Dijkhuizen, AJ Oskam. 1992. A dynamic model for cost-benefit analyses of foot-and-mouth disease control strategies. Prev Vet Med 12, 229-243.

Boklund A, T Halasa, LE Christiansen, C Enøe. 2013. Comparing control strategies against foot-and-mouth disease: Will vaccination be costeffective in Denmark? Prev Vet Med 111, 206-219.

Cohen NE, MAPM Van Asseldonk, EN Stassen. 2007. Social-ethical issues concerning the control of animal diseases in the European Union: a survey. Agriculture and Human Values 24, 499-510.

Dijkhuizen AA, RS Morris. 1997. Animal health economics : principles and applications. University of Sydney, Sydney, Australia.
Haydon DT, RR Kao, RP Kitching. 2004. The UK foot-and-mouth disease outbreak - the aftermath. Nature 2, 675-681.

Hoste R, RHM Bergevoet. 2007. Afzet vlees van gevaccineerde varkens: een verkenning van economische consequenties (Sales of meat from vaccinated pigs; An exploration of economic consequences). LEI, Den Haag, Netherlands. http://edepot.wur.n1/24576

Huirne RBM, MCM Mourits, F Tomassen, JJ De Vlieger, TA Vogelzang. 2002. Past, present and future situation of foot and mouth disease; on the prevention and control of foot and mouth disease epidemics. Agricultural Economics Research Institute, Wageningen UR, Wageningen, Netherlands. http://edepot.wur.nl/23273

Mangen MJJ, M Nielen, AM Burrell. 2002. Simulated effect of pig-population density on epidemic size and choice of control strategy for classical swine fever epidemics in The Netherlands. Prev Vet Med 56, 141-163.

Meuwissen MPM, SH Horst, RBM Huirne, AA Dijkhuizen. 1999. A model to estimate the financial consequences of classical swine fever outbreaks: principles and outcomes. Prev Vet Med 42, 249-270.

Meuwissen MPM, MAPM Van Asseldonk, RBM Huirne. 2003. Alternative risk financing instruments for swine epidemics. Agricultural Systems 75, 305-322.

Meuwissen MPM, MAPM van Asseldonk, MCM Mourits, RBM Huirne. 2009. Epidemic disease risk financing in a protective vaccination framework. Revista Española de Estudios Agrosociales y Pesqueros 21, 151-173.

Mourits MCM, MAPM van Asseldonk, RBM Huirne. 2010. Multi criteria decision making to evaluate control strategies of contagious animal diseases. Prev Vet Med 96, 201-210.

Parent KB, GY Miller, PJ Hullinger. 2011. Triggers for foot and mouth disease vaccination in the United States. Rev Sci Tech 30, 789-796.

Paton DJ, KJ Sumption, B Charleston. 2009. Options for control of footand-mouth disease: knowledge, capability and policy. Philos Trans $R$ Soc Lond B Biol Soc 364, 2657-2667.

Van Asseldonk MAPM, MPM Meuwissen, RBM Huirne, E Wilkens. 2006. Public and private schemes indemnifying epidemic livestock losses in the European Union: a review. In: Koontz DL, Hoag SRH, Thilmany DD (eds). The Economics of livestock disease insurance. CABI Publishing, Wallingford, UK.

Vrolijk HCJ, KJ Poppe. 2008. Income volatility and income crises in the European Union. Meeuwissen MMP, van Asseldonk MPM, Huirne RBM (eds). Income stabilisation in European agriculture. Wageningen Academic Publishers, Wageningen, Netherlands, Pp 33-54. 